Presented at CORROSION/99 Paper No. 99342

Copyrighted (C) by NACE International

Corrosion Testing Laboratories, Inc. 60 Blue Hen Drive, Newark, DE 19713

\title{
ANT NEST CORROSION -- EXPLORING THE LABYRINTH
}

\author{
Peter Elliott \\ Corrosion Materials Consultancy, Inc. \\ P.O. Box 37 \\ Colts Neck, NJ 07722 \\ Richard A. Corbett \\ Corrosion Testing Laboratories, Inc. \\ 60 Blue Hen Drive \\ Newark, DE 19713
}

\begin{abstract}
The phenomenon of ant nest (formicary) corrosion is reviewed. Current theories indicate that attack requires the simultaneous presence of moisture, oxygen and a corrodent, usually an organic acid, such as formic acid. Morphological features are presented using several recent case studies as examples. This paper seeks to create more answers to this less appreciated phenomenon that causes premature corrosion failure in copper tubes used typically for refrigeration or air conditioning applications.
\end{abstract}

\section{INTRODUCTION}

Ant-nest corrosion, sometimes referred to as formicary corrosion, describes a particular form of localized corrosion found in copper tubes used for refrigeration and air conditioning applications. The nature of the attack is of a submicroscopic nature; pits created by this type of corrosion are so fine that they are not visible to the unaided eye.

Typically the copper surface will be discolored adjacent to the corrosion pit(s). Surface films can vary from dull gray-black to red-brown or purple, depending upon the specific environment. The morphology of the corrosion damage within the metal comprises a series of minute interconnecting tunnels of random direction resulting from branching of the pits. The corrosion initiates from the tube

Key words: Ant nest, formicary, pitting, copper, micro-tunnels, organic acids, formic acid, heat exchangers, air conditioning, lubricating fluids 
surface and progresses rapidly into the tube wall. Perforation usually occurs in weeks or months, and not years. The unique morphology so closely parallels an ant's nest (remember as children we played with the Ant Farm), hence the terminology adopted to describe the phenomenon.

The micro-tunnels associated with ant nest corrosion are commonly filled with corrosion products, (i.e., $\mathrm{Cu}_{2} \mathrm{O}$ copper oxide) which may be transported to the tube surface forming a telltale tarnish film or scale as noted above.

Ant nest corrosion will only occur when oxygen, moisture and a specific corrodent, usually an organic acid, are simultaneously present on a copper surface. The damage is worse when stagnant fluids are retained against the copper surface or when crevices are part of the unit design. The most common cause of ant nest corrosion is the presence of chlorinated organic compounds or hydrolysis products produced by the decomposition of, for example, esters or aldehydes to carboxylic acids, such as formic or acetic.

The literature, ${ }^{(2-16)}$ references many sources of corrodents, including synthetic lubrication oils used in fabricating or joining copper tubes; degreasing and detergent cleaners (e.g., trichloroethane, trichloroethylene); inhibited antifreeze solutions used for winter storage; fluxes used for brazing or soldering copper tubes; volatile substances formed from vinegar seasonings, such as vegetable oil dressing and grain vinegar, liquid smoke, synthetic building materials, or cosmetics, such as eau de cologne.

Despite the significant input from Japanese workers during the last 15 years, ant-nest corrosion is a relatively unrecognized phenomenon in the rest of the world. The earliest report describing ant nesttype corrosion was attributed to failures in Belgium in $1965^{(18)}$. Later, micro-pitting damage to copper heat exchanger tubing was attributed to the breakdown of antifreeze inhibitors during storage of watercontaminated tubes. ${ }^{(1)}$ The term ant nest corrosion is attributed to Yamauchi ${ }^{(2)}$.

Of note, from the Japanese research, is the conclusion that approximately $10 \%$ of all premature failures of copper tubes result from ant nest corrosion ${ }^{(4,5,7)}$. Based on this fact alone the industry worldwide must recognize that ant nest corrosion, albeit not identified as such in most instances, accounts for many premature failures in copper products. Similar phenomenon have been observed in other alloy systems, but described as directional pitting, discontinuous micro-voids, porosity or successive pitting. ${ }^{(4)(14)}$

In exploring the phenomenon of ant nest corrosion this paper reviews current mechanisms of attack, summarizes expected morphologies, laboratory studies and presents the results of recent case studies involving refrigerated copper heat exchangers and air-conditioning systems.

\section{MECHANISM}

Studies have shown that the corrosion process occurs with the simultaneous presence of moisture, air and an organic acid. The general consensus regarding the mechanism of ant nest corrosion is a modified pitting process involving a small pit (termed a micro-anode) where copper oxidizes and dissolves according to:

$$
\mathrm{Cu}^{0} \rightarrow \mathrm{Cu}^{+}+\mathrm{e}^{-}
$$

Page 2 of 12

Presented at CORROSION/99 Paper No. 99342

Copyrighted (C) by NACE International

Corrosion Testing Laboratories, Inc. 60 Blue Hen Drive, Newark, DE 19713 
In the presence of carboxylic acid (e.g., formic acid) the copper ions react to form an unstable cuprous complex:

$$
\mathrm{Cu}^{+}+\mathrm{HCOO}^{-} \rightarrow \mathrm{Cu}(\mathrm{CHOO})
$$

This complex is oxidized to form cupric formate and cuprous oxide:

$$
4 \mathrm{Cu}(\mathrm{CHOO})+1 / 2 \mathrm{O}_{2} \rightarrow 2 \mathrm{Cu}(\mathrm{CHOO})_{2}+\mathrm{Cu}_{2} \mathrm{O}
$$

Micro cracks develop and radiate outward within the pit due to the wedging effect of the deposited cuprous oxide. The micro cracks expose more surfaces of copper and the process proceeds within the micro-crack to give the cuprous complex according to:

$$
\mathrm{Cu}(\mathrm{CHOO})_{2}+\mathrm{Cu}^{0} \rightarrow 2 \mathrm{Cu}(\mathrm{CHOO})
$$

Thereon, reactions 3 and 4 repeat over and over until tunnels are formed leading to through-wall penetration.

\section{MORPHOLOGY}

Morphologies associated with ant nest corrosion are purported to vary according to the corrodent in the environment ${ }^{(2)}$. The Japanese Petroleum Society ${ }^{(19)}$ even proposes a classification system. It is our belief that such attempts to rationalize the form of damage are less useful than is the need to create a better awareness and understanding of the phenomenon. Notoya ${ }^{(5)}$ has stated that attempts to classify ant nest corrosion would not be of practical value due to the number of definitions involved. It is our opinion that the user or manufacturer is less interested in whether the pits are circular, irregular, elliptical or whatever, rather that the phenomenon be eradicated.

From a research point of view it might be useful to note that certain pits are of a particular shape or coarseness, (Table 1). It is rare to associate service failures with grain boundary attack. ${ }^{(7)}$

From a practical point of view it is known that ant nest corrosion usually results following storage after assembly or following pressure testing for leaks ${ }^{(1,5,17)}$. There is some contradiction, based on the authors' studies over recent years, about where failures occur, Table 2.

Although probably contributory, there has been no report of any significant contribution to damage caused by local stresses in the copper tubes, grain size in the metal, nor bacterial corrosion.

\section{LABORATORY STUDIES}

Simulation studies in the laboratory have been successful in replicating ant nest corrosion found in the field. Laboratory tests are typically conducted in simple spring clamped Mason jars containing the corrodent fluid of interest. Our tests were performed on $1.9 \mathrm{~cm}(3 / 4$ in) diameter UNS C12200 (phosphorus deoxidized, high residual phosphorus (DHP) copper) tubes, $10 \mathrm{~cm}$ (4 in) in length. The surface was in the as-received condition. The tubes were internally rifled with a smooth outside. The tubes were placed in a glass test tube so as to avoid direct contact between the copper and the corrodent.

Page 3 of 12

Presented at CORROSION/99 Paper No. 99342

Copyrighted (C) by NACE International

Corrosion Testing Laboratories, Inc. 60 Blue Hen Drive, Newark, DE 19713 
The corrodents examined included $0.1 \%$ and $1 \%$ formic and $0.1 \%$ acetic acid, $90 \%$ 1,1,1-trichloroethane $10 \%$ water mixture, to reproduce the Japanese studies, and five water-based drawing and finning lubricants commercially used in the United States. To hydrolyze the solvent and the lubricants, the fluids were boiled in reflux flasks for 48 hours. The test solutions were placed in separate jars along with the copper containing glass tube. The jars were placed in a constant temperature oven at $40^{\circ} \mathrm{C}$ $\left(104^{\circ} \mathrm{F}\right)$ for 1 month.

Surface staining occurred on all copper samples. The coloration varied from dark purple to dark bluegreen to blue-gray to black. Cross-sections of the copper tubes after exposure revealed localized attack. In the formic and acetic acids the presence of branched tunnels was obvious. In the decomposed 1,1,1trichloroethane the pits were mostly spherical, with just the beginning of tunnel branching occurring. In the five drawing fluids, one had spherical pits only, three had branched tunnels and one had general surface attack.

\section{CASE STUDIES}

Two recent case studies are summarized in the following paragraphs. The first case involved small bore copper refrigerated heat exchanger bundles that occasionally were failing in less than two months service. The second case involved a chiller unit in a commercial air conditioning system that failed in less than one-year service. And, the third case also involved a chiller unit in a commercial air conditioning system that failed prior to start-up but sitting idle for seven months after hydro-testing.

\section{Case No. 1}

Background. Small bore, 3/16” OD copper tubes were failing within a few months service as a result of pin-hole pitting on the inside diameter (ID) air-side of the heat exchanger tubes, Figure 1. Quench water used following brazing or for leak testing was suspect in that the water was infrequently changed, and the facility (originally) had less than rigorous control on their assembly line and warehousing practices.

Features. The copper ID surfaces, revealed by splitting tubes longitudinally, were typically dullblack in appearance, sometimes with an oily-film present. Cross sections revealed ant nest corrosion damage, Figure 2, extending deep into the tube.

Considerations. Radical changes were made to the fabrication shop conditions and methods for warehousing the final heat exchanger assemblies. The frequency of failure was reduced significantly, although not entirely eliminated. The damaged areas were commonly purple in color.

FTIR (Fourier Transformation Infrared) analysis was conducted on wash-down products released from selected tube lengths using an acetone rinse. The FTIR spectra revealed bands due to hydrocarbon materials with a small amount of carbonyl functionality; typical of petroleum-based lubricants. Further spectra revealed alkylphenol-EO adducts (alkylphenol polyethylene glycol ethers) which are non-ionic surfactants, Figure 3. No bands were detected from FTIR Spectra on the as-received tubes.

The most recent changes in the facility included significant modification to the water used for cooling the as-assembled (brazed) systems. Included in the revisions were a new filter and an activated carbon absorber for de-chlorination. Water analyses conducted prior to these changes identified six volatiles or semi-volatiles species: bromoform, bromodichloromethane, dibromochloromethane, di-n-butyl

Page 4 of 12

Presented at CORROSION/99 Paper No. 99342

Copyrighted (C) by NACE International

Corrosion Testing Laboratories, Inc. 60 Blue Hen Drive, Newark, DE 19713 
phthalate, bis(2-ethylhexyl)phthalate, and ethanol 2-(1-methyloxy). Based upon theoretical considerations, three of these (see below) provide a source of formic acid, and are therefore possible promoters of ant nest corrosion.

Specifically the following reactions can be considered:

1. Bromoform

$$
\begin{aligned}
& \mathrm{CHBr}_{3}+\mathrm{H}_{2} \mathrm{O} \rightarrow \mathrm{HBr}+\mathrm{CHBr}_{2} \mathrm{OH} \\
& \mathrm{CHBr}_{2} \mathrm{OH}+\mathrm{H}_{2} \mathrm{O} \rightarrow \mathrm{HBr}+\mathrm{CHBrO}+\mathrm{H}_{2} \mathrm{O} \\
& \mathrm{CHBrO}+\mathrm{H}_{2} \mathrm{O} \rightarrow \mathrm{HBr}+\mathrm{CHOOH} \\
& 3 \text { moles of } \mathrm{HBr} \text { are formed with formic acid. }
\end{aligned}
$$

2. Bromodichloromethane

$$
\begin{aligned}
& \mathrm{CHBrCl}_{2}+\mathrm{H}_{2} \mathrm{O} \rightarrow \mathrm{HBr}+\mathrm{CHCl}_{2} \mathrm{OH} \\
& \mathrm{CHCl}_{2} \mathrm{OH}+\mathrm{H}_{2} \mathrm{O} \rightarrow \mathrm{HCl}+\mathrm{CHClO}+\mathrm{H}_{2} \mathrm{O} \\
& \mathrm{CHClO}+\mathrm{H}_{2} \mathrm{O} \rightarrow \mathrm{HCl}+\mathrm{CHOOH}
\end{aligned}
$$

2 moles of $\mathrm{HCl}$ and 1 mole of $\mathrm{HBr}$ are formed for every mole of formic acid.

\section{Dibromochloromethane}

$$
\begin{aligned}
& \mathrm{CHBr}_{2} \mathrm{Cl}+\mathrm{H}_{2} \mathrm{O} \rightarrow \mathrm{HBr}+\mathrm{CHBrClOH} \\
& \mathrm{CHBrClOH}+\mathrm{H}_{2} \mathrm{O} \rightarrow \mathrm{HBr}+\mathrm{CHClO}+\mathrm{H}_{2} \mathrm{O} \\
& \mathrm{CHClO}+\mathrm{H}_{2} \mathrm{O} \rightarrow \mathrm{HCl}+\mathrm{CHOOH}
\end{aligned}
$$

2 moles of $\mathrm{HBr}$ and 1 mole of $\mathrm{HCl}$ form for every 1 mole of formic acid.

The extent of corrosion will be a function of the rate of formic acid formation which will be influenced by temperature, $\mathrm{pH}$, etc.

Of note in certain cross-sections was the presence of fine cracks bridging individual pitted areas, (Figure 4). This may indicate some local contributions from internal stresses in the material. It is noted that cracks are not a commonly reported phenomenon in ant nest corrosion.

\section{Page 5 of 12}

Presented at CORROSION/99 Paper No. 99342

Copyrighted $\odot$ by NACE International

Corrosion Testing Laboratories, Inc. 60 Blue Hen Drive, Newark, DE 19713 


\section{Case No. 2}

Background. An industrial air conditioning system had been fabricated in June 1996, put into service in April 1997, and failed the following March (1998). Eddy current analysis indicated which tubes were suspected of leaking, and were confirmed by a pressure test and a leak detection probe. Condenser and evaporator tubes were affected. Cooling or heat transfer water ran through the tubes, and fluorocarbon refrigerant was on the shell side. Water treatment was used, but the details were unknown.

Features. In the as-received condition, the outside diameter (OD) surfaces of the tubes had a reddish-copper color with areas of random black staining. There was no obvious attack, even under microscopic examination. Longitudinal cutting of the tubes revealed the ID surfaces. Under the microscope, small bits of debris and sand particles were observed, and presumed to have come form the cooling tower water. A random black scale, Figure 5, was present which could not be removed by mere scrubbing with a firm toothbrush. Inhibited hydrochloric acid was employed to remove the deposits on the tube, however, the black scale resisted chemical cleaning. At 40X magnification, small pit-like features were observed in the midst of the black scale, Figure 6. Cross-sections revealed extensive ant nest corrosion extending through the tube wall, Figure 7.

Considerations. It was reported, although not confirmed, that the black stains on the OD were present in the as-received condition from the tube manufacturer. It is known that the tube manufacturer, over the course of the last seven years had phased out from using a petroleum-based drawing / finning lubricant and chlorinated hydrocarbon degreaser to a synthetic-based, water soluble drawing / finning lubricant and a hot water rinse. The changes were based on an increasingly reported rate of pitting failures, and the similarity of their failures compared to those reported by the Japanese relating to ant nest corrosion.

The synthetic-based, water-soluble lubricants are ester-based fluids. The FTIR analysis on chloroform ID rinsed tube lengths agreed with this lubricant, indicating that significant amounts had been retained even after hot water rinsing.

Laboratory studies, as described above, were performed on a sample of the drawing / finning lubricant used at the tube manufacturing mill. The tests produced blue-black and black stains on the surfaces and branched tunneling was revealed from the cross-sections. These results confirmed the suspicion that the stains were present when received from the mill and that this was a lubrication related failure.

The tube mill and chiller manufacturer are addressing the issue of lubricants, but as yet no decision has been made to change these fluids. A more intense rinsing program has been initiated, with considerations to use copper inhibitors and hot air drying.

\section{CONCLUSIONS}

Ant nest corrosion is a real phenomenon associated with the premature failure of copper tubes used principally for refrigeration or air conditioning applications. The fact that the phenomenon is less well known is alarming because of the high number of failures that may be attributed to other forms of corrosion by those less informed. Most commonly, corrosion of copper tubing for the air conditioning industry is usually classified as water side erosion, obvious pitting or corrosion fatigue. However, there are cases where corrosion does not exactly fit into these categories. These case studies encountered one of these situations.

Page 6 of 12

Presented at CORROSION/99 Paper No. 99342

Copyrighted (C) by NACE International

Corrosion Testing Laboratories, Inc. 60 Blue Hen Drive, Newark, DE 19713 
The nature of ant nest corrosion may reveal itself in a variety of forms, although always the visual damage of the surface pits is not detectable to the unaided eye. As to whether the pits that tunnel into a metal adopt specific shapes or follow certain patterns is academic in that damage will be reduced or eliminated if copper surfaces are properly cleaned and kept dry.

\section{REFERENCES}

1. J. O. Edwards, R. I. Hamilton, J. B. Gilmour, Materials Performance, 16, 9 (1977): p. 18.

2. S. Yamauchi, K. Nagata, S. Sato, M. Shimono, Journal Of The Japanese Copper and Brass Research Association 22 (1983): p 132, also Sumitomo Light Metal Technical Reports, 25, 1 (1984): p. 1.

3. T. Notoya, T. Hamamoto, K. Kawano, Corrosion Engineering (Japan), 37, 2 (1988): p. 1.

4. T. Notoya, T. Hamamoto, K. Kawano, Sumitomo Light Metal Technical Reports, 30, 3 (1989): p. 9.

5. T. Notoya, Corrosion Engineering, 39 (1990): p. 353.

6. T. Hamamoto, M. Imai, Sumitomo Light Metal Technical Reports, 33, 4 (1991): p. 23.

7. G. Isobe, et. al., NACE Corrosion Asia, paper 106 (1992)

8. T. Takahashi, et. al., Journal of the Japan Copper and Brass Research Association, 31 (1992): p. 135.

9. K. Nagata, K. Kawano, Sumitomo Light Metal Technical Reports, 35 (1993): p. 28.

10. T. Notoya, Materials Performance, 32, 5 (1993): p. 53.

11. Miyafuji, et. al., Journal of the Copper and Brass Research Association, 33 (1994): p. 7.

12. H. Baba, T. Kodama, Corrosion Engineering (Japan) 44, 4 (1995): p. 279.

13. R. S. Lenox, P. A. Hough, ASHRAE Journal, 11 (1995): p. 50.

14. R. A. Corbett, W. S. Morrison, D. F. Bickford, Materials Performance, 26, 2 (1987): p. 40.

15. T. Notoya, Corrosion Engineering (Japan), 46 (1997): p. 319.

16. T. Notoya, Zairya-to-Kankyo, 46 (1997): p. 731.

17. G. Tetley, M. Heidenreich, K. Smith, Air Conditioning, Heating \& Refrigeration News, 203, 13 (1998): p. 5; personnel communication (G. Tetley).

18. J. M. Keyes, International Copper Research Association Symposium, Belgium, June 14-15, 1965.

19. Japanese Petroleum Society: Collected Photographs of Corrosion Morphology, Revised Edition (1968): p. 189.

Page 7 of 12

Presented at CORROSION/99 Paper No. 99342

Copyrighted (C) by NACE International

Corrosion Testing Laboratories, Inc. 60 Blue Hen Drive, Newark, DE 19713 
TABLE 1

MORPHOLOGY OF ANT NEST CORROSION ${ }^{(2)(10)}$

\begin{tabular}{|c|c|}
\hline Corrodent & Morphology of pits \\
\hline $\begin{array}{l}\text { Formic acid } \\
\text { Dichloroacetic acid } \\
\text { N-butylacetate }\end{array}$ & Irregular shaped pits \\
\hline Acetic acid & Round-shaped pits \\
\hline $\begin{array}{l}\text { Propionic acid } \\
\text { N-butyric acid } \\
\text { Aldehydes }\end{array}$ & Finer structure compared to above \\
\hline $\begin{array}{l}\text { HF (one second) } \\
\text { Plus moist oxygen (1 month) }\end{array}$ & Directional pits \\
\hline
\end{tabular}

TABLE 2

EVIDENCE FOR ANT NEST CORROSION IN SERVICE

\begin{tabular}{|l|c|c|}
\hline \multicolumn{1}{|c|}{ Feature } & Japanese Survey $^{(10)}$ & \multicolumn{1}{c|}{ Current Authors } \\
\hline Damage from OD & $60 \%$ & - \\
\hline Damage from ID & $34 \%$ & $100 \%$ \\
\hline Damage in straight pipe & $66 \%$ & - \\
\hline Damage in bent pipe & $31 \%$ & - \\
\hline Damage in soldered parts & $3 \%$ & $\begin{array}{l}\text { All, worse attack beneath the } \\
\text { black deposits }\end{array}$ \\
\hline $\begin{array}{l}\text { Red/brown } \\
\text { Purple- black } \\
\text { Discoloration }\end{array}$ & All & \\
\hline
\end{tabular}

Page 8 of 12

Presented at CORROSION/99 Paper No. 99342

Copyrighted (C) by NACE International

Corrosion Testing Laboratories, Inc. 60 Blue Hen Drive, Newark, DE 19713 


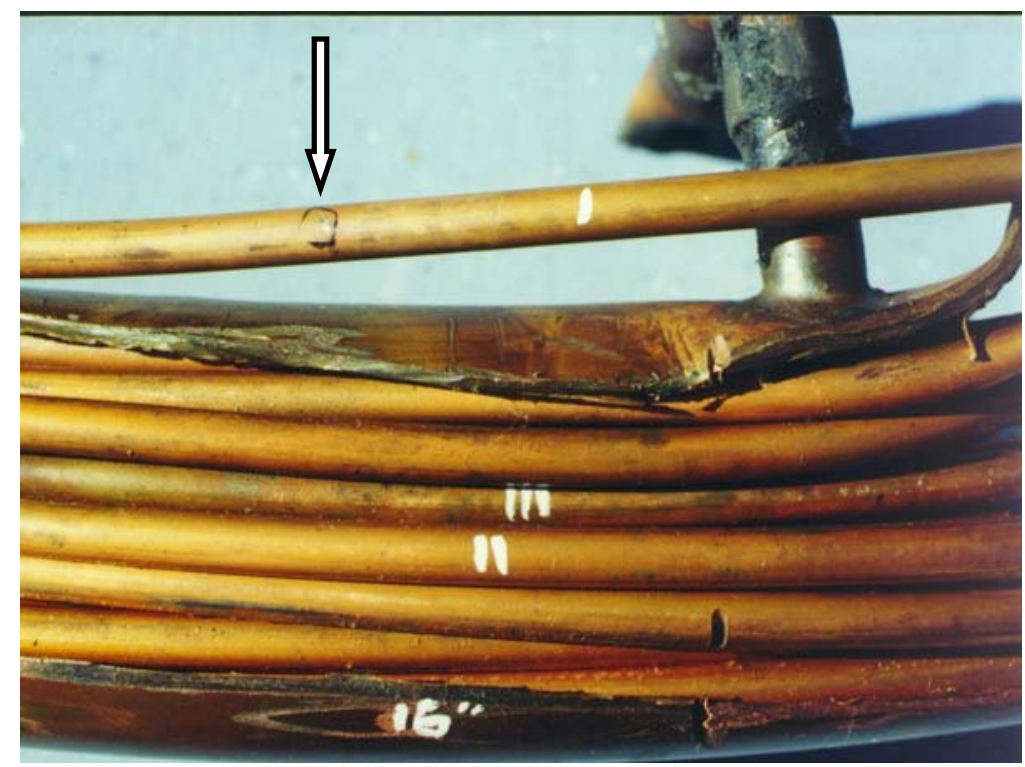

Figure 1. Ant-nest corrosion in 3/16-inch diameter copper heat exchanger tubes after approximately two months service. Arrow points to pin hole.

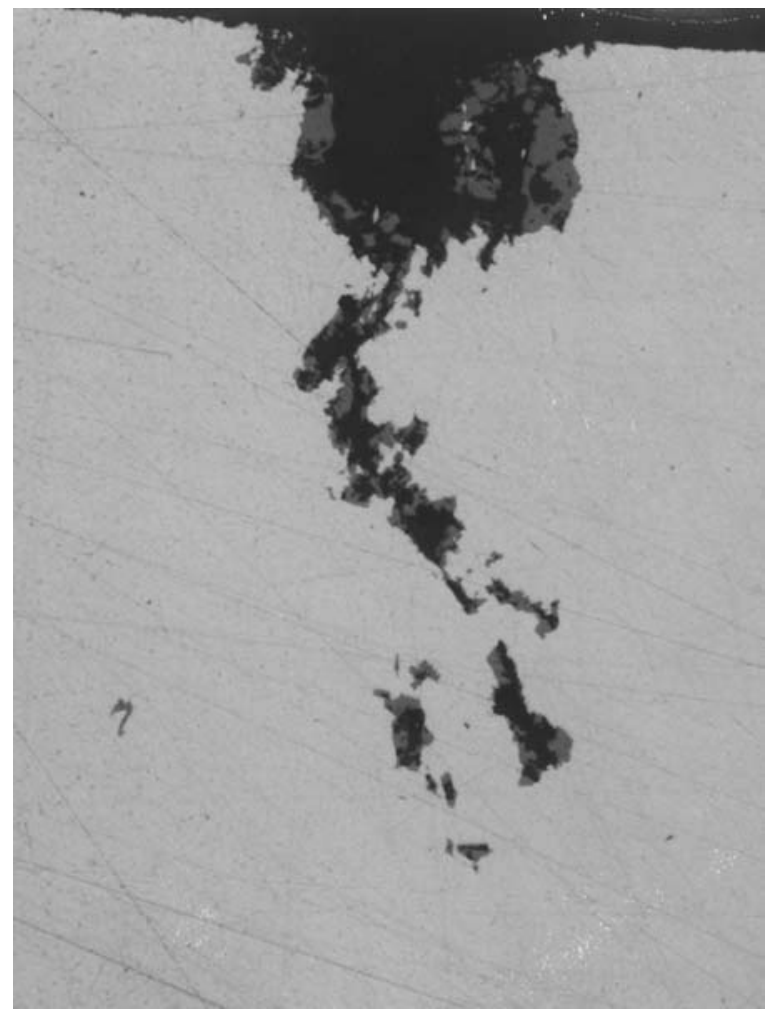

Figure 2. Cross-section showing ant nest corrosion in a heat exchanger tube after 6 weeks from fabrication. (original magnification 200X)

Page 9 of 12

Presented at CORROSION/99 Paper No. 99342

Copyrighted (C) by NACE International

Corrosion Testing Laboratories, Inc. 60 Blue Hen Drive, Newark, DE 19713 

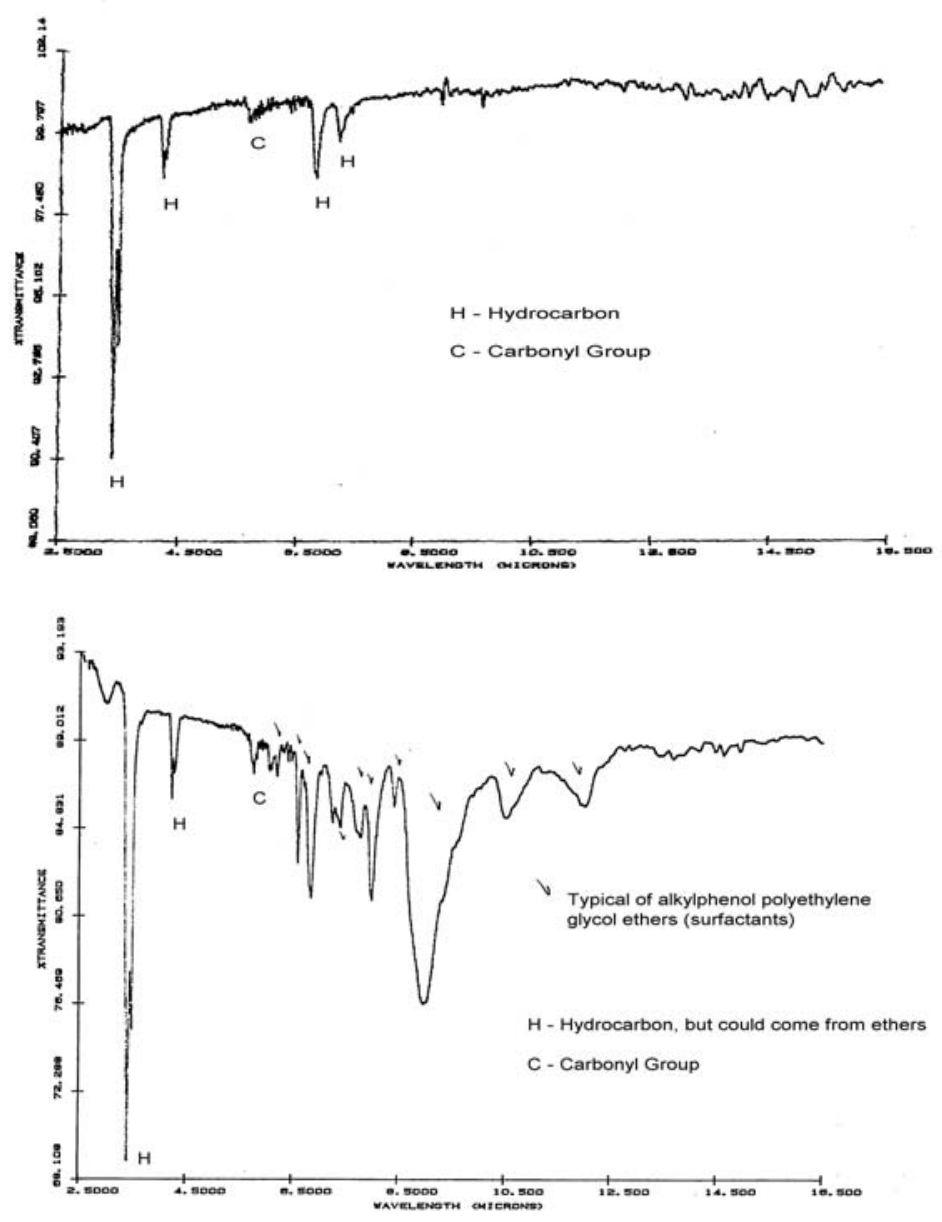

Figure 3. Infrared (FTIR) spectra of ID products

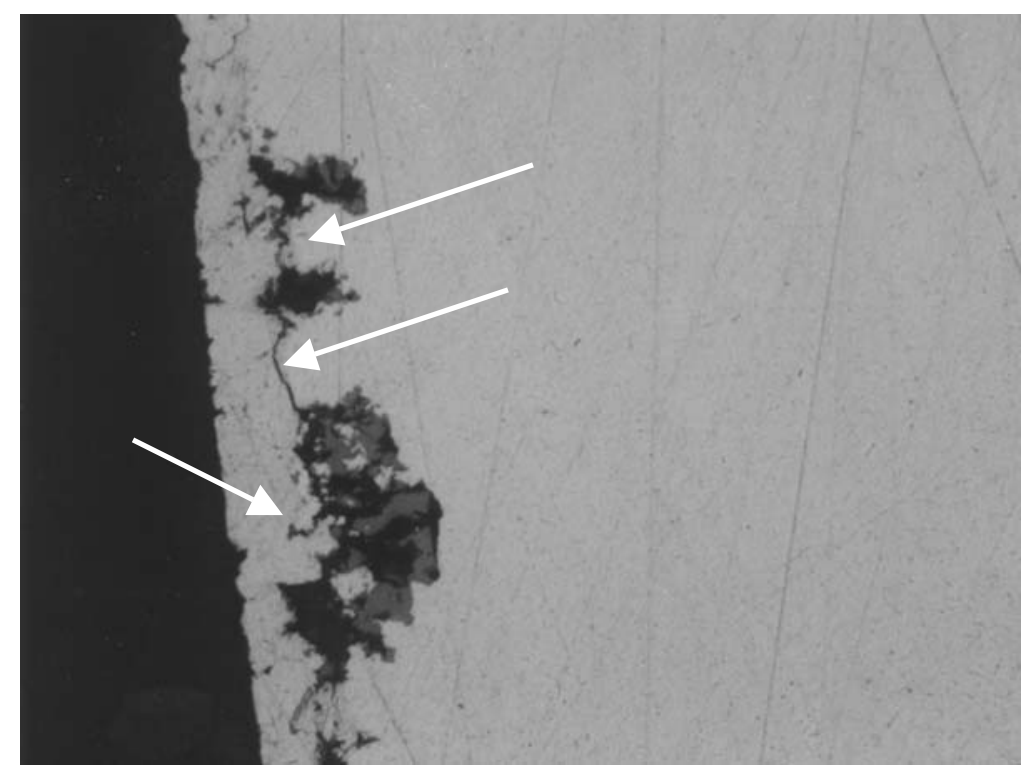

Figure 4. Fine cracks (at arrows) inter-linking pits associated with ant nest corrosion.

Page 10 of 12

Presented at CORROSION/99 Paper No. 99342

Copyrighted (C) by NACE International

Corrosion Testing Laboratories, Inc. 60 Blue Hen Drive, Newark, DE 19713 


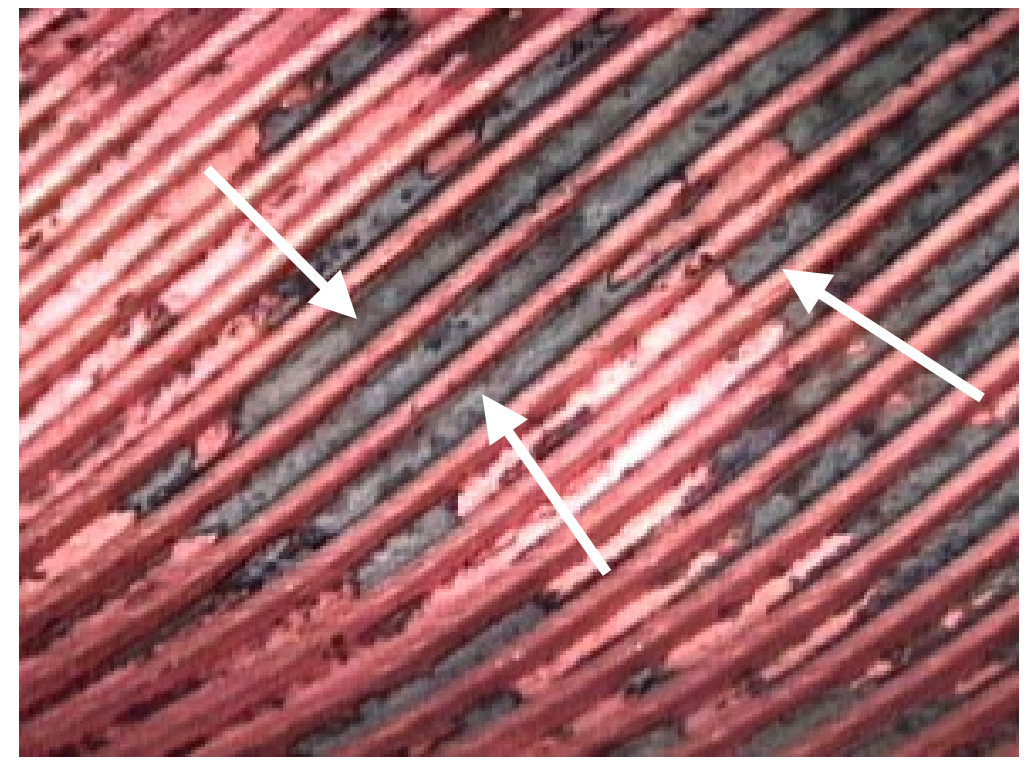

Figure 5. Semi-cleaned condenser tube ID. Arrows indicate areas of black scale and pitting attack. (10X original magnification)

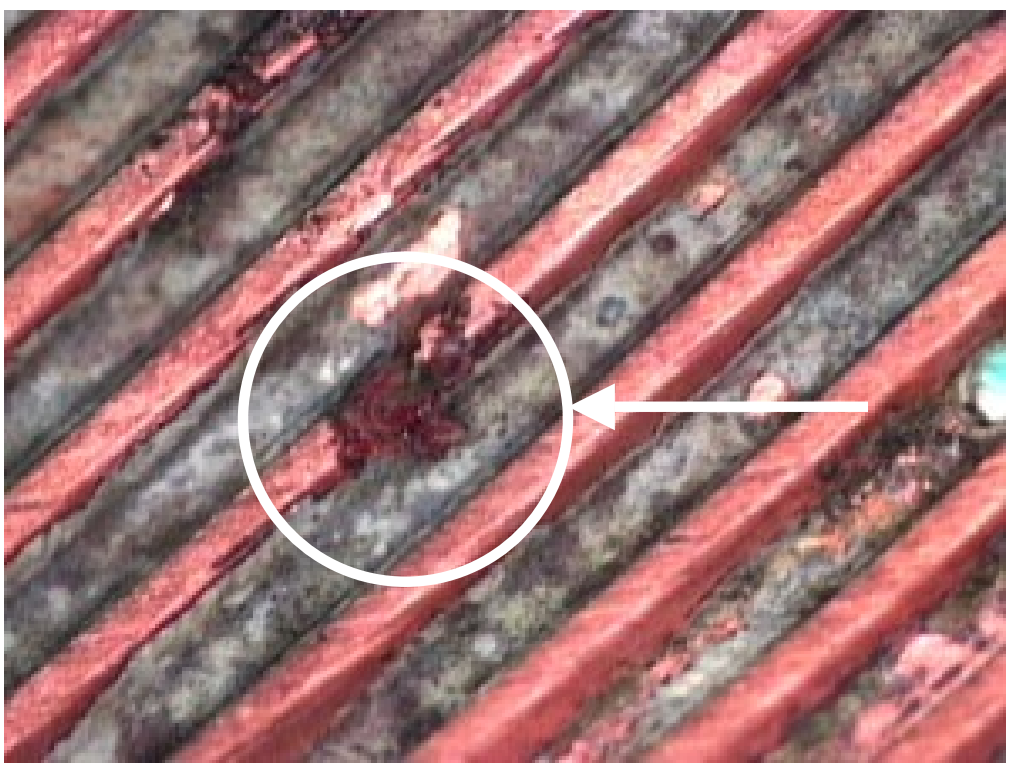

Figure 6. Semi-cleaned condenser tube ID. Arrow indicates area of substantial pitting attack. The rifled ridge is completely gone. (40X original magnification)

Page 11 of 12

Presented at CORROSION/99 Paper No. 99342

Copyrighted (C) by NACE International

Corrosion Testing Laboratories, Inc. 60 Blue Hen Drive, Newark, DE 19713 


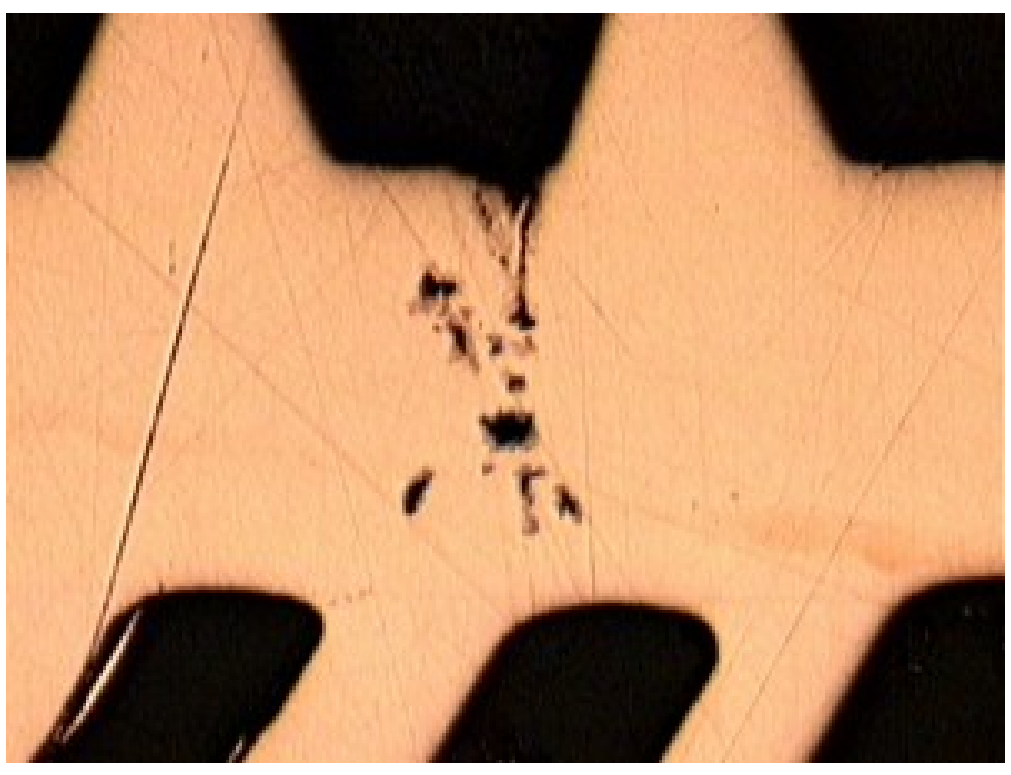

Figure 7. Cross-section of evaporator tube. (ID is at top). Note the near through-wall penetration of the tunnels. Pit originates on ID surface, top. (60X original magnification) 